\title{
Wealth and Words: Pope's "Epistle to Bathurst"
}

\section{Citation}

Engell, James. 1988. Wealth and words: Pope's "Epistle to Bathurst". Modern Philology 84(4): 433-446.

\section{Published Version}

http://dx.doi.org/10.1086/391654

\section{Permanent link}

http://nrs.harvard.edu/urn-3:HUL.InstRepos:3355447

\section{Terms of Use}

This article was downloaded from Harvard University's DASH repository, and is made available under the terms and conditions applicable to Other Posted Material, as set forth at http:// nrs.harvard.edu/urn-3:HUL.InstRepos:dash.current.terms-of-use\#LAA

\section{Share Your Story}

The Harvard community has made this article openly available.

Please share how this access benefits you. Submit a story.

\section{Accessibility}




\title{
Wealth and Words: Pope's Epistle to Bathurst
}

\author{
James Engell
}

You know the use of riches...

[Mosca to Volpone, 1.1]

\section{I}

The Epistle to Bathurst has such genius of compression that we might think of it as four hundred lines, four hundred times that scope. In 1960 Earl Wasserman noted that the poem moves on several levels in a "climate of attitudes." ${ }^{2}$ This essay examines one level: the commingling in phrase, imagery, and theme of two key social systems of signification and value, money and language. As structuralist and poststructuralist critics (among them Barthes, de Man, Culler, Kristeva, Derrida, and Riffaterre) have repeatedly pointed out, language is a system of symbolic differences whose meanings come from an essentially tacit social agreement, established through education and memory, in which individuals treat each word as signifying roughly the same idea. Possessing no intrinsic or natural connection with things in themselves, words in this sense are "arbitrary" or artificial. Only by communal consent do they represent specific value. Some structuralist and deconstructive critics have persisted in calling this view of language revolutionary, a contribution primarily of Ferdinand de Saussure early in this century. Many of his insights were fresh and have been extended. Yet this general view of language may be traced back at least to the Middle Ages - as Umberto Eco and others assert-and gained concise, modern articulation in Locke's Essay Concerning Human Understanding. In book 4 Locke first introduces semiotic into modern English discourse. Semiotics constitutes his third branch of knowledge: "the third branch may be called

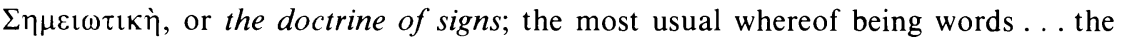
business whereof is to consider the nature of signs the mind makes use of for the understanding of things. ... therefore to communicate our thoughts to one another, as well as record them for our own use, signs of our ideas are also necessary" (Locke, 4.21).

Linguists have noted, too, that language is a form of currency. Numerous analogies and metaphors remind us that words and the counters of wealth are

\footnotetext{
1/ While Pope composed the Epistle, 1730-32, Volpone reached its greatest popularity on the eighteenthcentury stage. See R. G. Noyes, Ben Jonson on the English Stage, 1660-1776 (Cambridge, Mass., 1935), pp. 69-70. This is noted by Graham Nicholls, who identifies another verbal parallel with the play in "Two Notes on Pope's 'Epistle to Bathurst," Notes and Queries 219 (1974): 251-52. The "use of riches" and other phrases in the poem also echo Isaac Barrow's sermons, which Pope read. See Peter Dixon, The World of Pope's Satires (London, 1968), p. 148 and n.

2/Earl R. Wasserman, Pope's "Epistle to Bathurst": A Critical Reading with An Edition of the Manuscripts (Baltimore, 1960); this is indispensable criticism. Also helpful are Reuben A. Brower, Alexander Pope: The Poetry of Allusion (London, 1959), pp. 251-60; Maynard Mack, The Garden and the City: Retirement and Politics in the Later Poetry of Pope, 1731-1743 (Toronto, 1969), pp. 86-89, 173-74n., esp. on Horatian allusion and the figure of Walpole in the poem, and Alexander Pope: A Life (New York and New Haven, Conn., 1986), pp. 513-21; Howard Weinbrot, Alexander Pope and the Traditions of Formal Verse Satire (Princeton, N.J., 1982), pp. 175-79; and David B. Morris, Alexander Pope: The Genius of Sense (Cambridge, Mass., 1984), pp. 182-88, 192, 205.
} 
connected habitually. To coin a phrase, money talks. Horace plays directly on this sense of linguistic currency in Ars Poetica, which Roscommon translates:

Men ever had, and ever will have, leave

To coin new words well suited to the age.

Words are like leaves, some wither ev'ry year,

And ev'ry year a younger race succeeds.

Pope, who praises Roscommon at the end of the Essay on Criticism, knew these lines and their original well. The half-line simile, "Words are like leaves," Pope applies to a different context earlier in the Essay:

Words are like Leaves; and where they most abound, Much Fruit of Sense beneath is rarely found.

[Lines 309-10]

Words as coin, words as leaves: the two images, connected through good usage guided by "sense," are embedded in Pope's associations and language.

But as artificial or arbitrary signifiers, neither money as units of capital, nor words as units of language, stand absolutely or naturally for particular things or virtues. Instead, words and wealth (whether land, gold, credit, or paper currency) take on meaning and value through social convention and action. Various uses and usages within each semiotic system may be judged proper or improper. ${ }^{3}$ Furthermore, the two systems have always been, on one level, perfectly interchangeable at no discount. As Fernand Braudel, eminent historian of capitalism and material economy, points out: "As soon as men had known how to write and had had coins to handle they had replaced cash with written documents, notes, promises and orders. Notes and cheques between market traders and bankers were known in Babylon twenty centuries before the Christian era." ${ }^{4}$

II

Pope's poem begins with an argument about the origin of gold. Like two schoolmen, he and Bathurst exchange explanations. Their introductory dialogue is verbal disputation, Doctors disagreeing over a theosophical point: "You hold the word, from Jove to Momus giv'n," while Pope contradicts this and will "Opine, that Nature, as in duty bound, / Deep hid the shining mischief under ground."5 But when the brief dispute ends, their words signifying different views are found to have

3/For one study relating language to economic exchange, see Timothy J. Reiss, Tragedy and Truth: Studies in the Development of a Renaissance and Neoclassical Discourse (New Haven, Conn., 1980), chap. 10, "Classicism, the Individual, and Economic Exchange (Iphigénie)," pp. 240-58, esp. n. 8, pp. 245, 322-23. Reiss employs a suggestive but strained ingenuity in interpreting the language and action of the play as contractual arrangement. Absent is direct consideration of writing, words, and wealth in the manner Pope presents explicitly. The same strain accompanies another attempt, through semantic structuralism, to connect economic exchange, value, and language in Jean Joseph's Crébillon fils: Economie érotique et narrative (Lexington, Ky., 1984). The best extended study remains Marc Shell, Money, Language, and Thought: Literary and Philosophical Economies from the Medieval to the Modern Era (Berkeley, 1982), esp. pp. 99-111. Shell does not discuss Pope, however.

4/Fernand Braudel, Capitalism and Material Life, 1400-1800, trans. Miriam Kochan (New York, 1974; originally published as Civilisation Matérielle et Capitalisme [Paris, 1967]), p. 359; hereafter CML.

5/Quotations from Bathurst are cited from The Twickenham Edition of the Poems of Alexander Pope, general ed. John Butt, vol. 3, pt. 2, ed. F. W. Bateson, Epistles to Several Persons (Moral Essays) (London and New Haven, Conn., 1951). 
concealed identical tenets. Both agree that gold creates the prodigal and the avaricious miser. ${ }^{6}$ The opening argument, with its "soundest" casuistry of opposites, a casuistry which Pope elsewhere scoffs at and discredits (e.g., Rape, 5.122, and Dunciad, 4.642), becomes balanced, at least temporarily. One account of the situation clears the other. There is a Christian-pagan tension here, whether gold comes from Jove or God, but the opening is more a rendering of Buchgeld or bookmoney (the contemporary German term, reflecting its written act of settling one account against another). Gold itself, and generally all wealth, though extreme in its gifts and debatable in origin, owes its moral worth completely to tenets directing its use. Plenty or penury makes no difference in virtue or salvation. Riches are not a sign or, to use Pope's word--with its monetary echo even louder then than now-a "token of th' Elect."

Gold, the traditional currency, is less cumbersome than wealth in kind, the production of goods themselves, such as hogsheads of wine or bellowing oxen. Even so, the bribe of golden guineas taken by the "old Patriot," more fully described in Pope's note, is discovered when the hypocrite leaves the King's closet and descends the back stairs. (We might recall, too, that a bribe itself involves a verbal or written promise, in this case to make an insincere speech aimed at gaining William III more money.) The Patriot's purse splits, out drops a guinea, and the coin betrays him to his Party by actually speaking,

And gingling down the back-stairs, told the crew,

"Old Cato is as great a Rogue as you."

\section{[Lines 67-68]}

Although gold is less bulky than physical objects on which we base wealth, it too grows heavy and speaks. It can weigh one down and turn tattle-tale. But Pope carries the parallel of money and words further. The ultimate in silence, and virtually weightless, is the gentle whisper of a paper leaf. Here the fusion of wealth and words, becoming quite complex, centers on writing as well as speech. Paper money is watermarked and inscribed, usually as a promissory note that bears a signature or signatures denoting a guarantee, someone's or some government's word of honor that the note can be exchanged for gold or silver at will. (Until recently U.S. notes promised in writing to pay the bearer on demand the stated sum in silver.) Paper money represents a bill or real debt, which the holder may claim any time. Its denomination refers to the amount written in words and accompanied by a signature, for as with personal checks, numbers can be altered with ease. Words-paper and ink-become the least bulky of all currencies, the well-languaged form of riches and deceit:

Blest paper-credit! last and best supply!

That lends Corruption lighter wings to fly!

Gold imp'd by thee, can compass hardest things,

Can pocket States, can fetch or carry Kings...

[Lines 69-72]

6/ Weinbrot refers to this "as an emblem of dialectic" (p. 175). Wasserman sees it as the rhetorical figure of epitrope (p. 21) and notes the background of Aristotle's Nicomachean Ethics for the poem's design as a whole (pp. 36-38).

7/Bateson (pp. 89-90n.) elaborates Pope's note. 
In 1694, when Pope was six years old, the Bank of England introduced government paper notes. All Europe admired the innovation. ${ }^{8}$ Pope seems to have the Bank notes uppermost - though not exclusively - in mind, especially since the episode of the speaking guinea occurred in 1698 and immediately precedes the apostrophe to money's "last and best supply!" Paper credit in its general sense already had a long history for personal and bank debts. As Tapwell sneers at the prodigal Wellborn in Massinger's A New Way to Pay Old Debts, "You grew the common borrower; no man 'scap'd/Your paper-pellets" (1.1). For centuries, writing was a sign of not having actual coinage, gold, silver, or copper, in hand. Government bank notes emerged by a process of evolution sped up in late seventeenth-century England. ${ }^{9}$ But paper notes, in denominations too large for the great mass of the populace to find practicable or even to possess, retained a mysterious aura decades after their first appearance. Echoing Paul (2 Thess. 2:7), Bolingbroke spoke of the establishment of public credit as a "whole mystery of iniquity." "Even in 1752," notes Braudel, "a man of the intellectual calibre of David Hume... spoke of 'that new invention of paper money' when the Bank of England had been issuing notes since it was founded in 1694." ${ }^{10}$ Suspicion and discomfort clung to this novel way of writing value.

But beyond his ironic paean to paper credit, more specifically to England's new paper notes, Pope transforms paper wealth into Sibylline leaves. (Eighty-five years later Coleridge would choose the same phrase as the title of his 1817 collection of poems.) The Sibylline Books, or at least three of the original nine, were consulted by Roman officials in time of state emergency. The Sibyl at Cumae was of course the poet(ess) who wrote prophecies on her leaves and cast them to the winds. In a single simile,

A leaf, like Sibyl's, [shall] scatter to and fro

Our fate and fortunes, as the winds shall blow,

Pope connects writing, the prophecy of empires, leaves, words, paper money, wind, flying, corruption, and, through a note of his own, refers the whole to Virgil. As Maynard Mack stresses, here is "fortune-hunting' of another kind," where "the evocation... of the palm leaves on which the Cumaean sibyl was reputed to scratch her prophecies ... strikes a note that vibrates through the poem." At first

8/For relevant background discussion, see Howard Erskine-Hill, "Pope and the Financial Revolution," in Writers and Their Backgrounds: Alexander Pope, ed. Peter Dixon (Athens, Ohio, 1972), pp. 200-229, and The Social Milieu of Alexander Pope (New Haven, Conn., 1975), pp. 103-31, 166-203. Braudel summarizes: "The innovation of the Bank of England was that it added ... a deliberately organised issuing bank, capable of offering ample credit in notes (whose total amount in fact far exceeded actual deposits)." Thus "It was like no other. . . Its originality lay in the fact that it put into circulation notes of over twenty pounds sterling to begin with, and of five, ten and fifteen pounds later. Eventually the smallest notes were for ten pounds, the largest for a thousand, all bearing the signatures of the directors of the Bank" (CML, pp. 360, 365-66).

9/For details, see P. G. M. Dickson, The Financial Revolution in England (Oxford, 1967), used by ErskineHill. Braudel gives a swift overview: "There are notes and notes. In the first place governmental orders, prototypes of bank notes, had multiplied in England from 1667 and the use of goldsmiths' notes, later called bankers' notes, was common earlier, in the middle of the century, for the London goldsmiths received silver on deposit against notes... The bank note was born almost spontaneously from commercial usage. It was a matter of urgent necessity" (CML, p. 360).

10/Dixon, p. 136, quotes Bolingbroke's "Dissertation upon Parties," first published as Craftsman no. 443; $C M L$, p. 358.

11/Mack, Alexander Pope: A Life, p. 515. Wasserman (pp. 25, 32) sees the Sibylline leaves touching both pagan and Christian contexts. 
glance Bateson's note seems to refer to line 116 of the sixth book of the Aeneid, but the citation is to Dryden's translation then quoted (lines 116-17). The passage and its context merit examination. In Virgil the lines are actually 6.74-76:

\author{
foliis tantum ne carmina manda \\ ne turbata volent rapidis ludibria ventis: \\ ipsa canas oro...
}

Aeneas asks Apollo and his Sibyl specifically not to write, not to use a leaf as paper or note, but to relate Aeneas's duty verbally, ipsa canas oro. Dryden, as Wasserman observes, renders this passage:

But, oh! commit not thy prophetic mind
To flitting leaves, the sport of every wind,
Lest they disperse in air our empty fate:
Write not, but, what the powers ordain, relate.

[Lines 116-19]

Whenever and wherever paper money was introduced, many found its nature and influence positively satanic. "If most contemporaries found money a 'difficult cabbala to understand," says Braudel, "this type of money, money that was not money at all, and this interplay of money and mere writing to a point where the two became confused, seemed not only complicated but diabolical."12 The invention of paper money in Goethe's Faust (2), which so greatly aids the Emperor, is one of Faust's major modern achievements, aided by the Devil's ingenuity. Goethe associates it, as does Pope, with gaming and luxury.

Now combine this sense of a prophetic, devilish currency with the common Opposition portrayal of Walpole as the great Satan or tempter, and through the images and allusions, a finger is clearly pointed at government financial measuresand the men behind them. (Craftsman no. 297, for instance, portrays Walpole as a tempter casting down from the "tree of corruption" apples variously labeled forfeited estates, charitable corporation, bank contract, South-Sea, etc.) Pope has such a nexus in mind when he writes about money as corrupt, prophetic leaves written upon with "lighter wings to fly." These are winged words of a special kind. We can recall Pope's insistence later in the poem on calling the Devil the Prince of Air, who flies, causes shipwrecks, and rouses whirlwinds. Probably Pope did not know that the Cantonese had for centuries called paper currency "flying money." Yet very possibly he did hear the Dutch term for the type of share speculation that had fueled the South Sea Bubble and compounded the national debt: Windhandel, or trading in air. Whitwell Elwin and W. J. Courthope, in their edition of Pope's Works, quote a similar metaphor used by Adam Smith later in the century: "The gold and silver money which circulates ... may very properly be compared to a highway, which, while it circulates and carries to market all the grass and corn of the country, itself produces not a single pile of either. The judicious operations of banking, by providing ... a sort of waggon-way through the air, enable the country to convert ... a great part of its highways into pastures and cornfields, and thereby to increase very considerably the annual produce of its land and labour."13

12/CML, p. 358; emphasis added.

13/The Works of Alexander Pope, ed. Whitwell Elwin and William John Courthope (London, 1871-89), 3:132, citing Smith's Wealth of Nations. 
Should all this be read as Pope's pure indictment of government notes? Contemporary moralists routinely damned speculation, credit, paper money, and banking. Yet Pope skirts this group of nay-sayers, at least to some degree. He and Bathurst seem resigned to the relatively new phenomenon of paper money; its tide is irreversible. ${ }^{14}$ But more importantly, Pope recognizes how money in the form of the written word can be misused with particular ease and stealth. Intent to keep an eye peeled for the end or uses to which wealth is put, whether in goods, gold, or paper, he is painfully aware how paper especially - that is, writing-offers opportunities for an empire without bound of deception and avarice, whether in notes, stock speculation, or even conveyances and wills drawn up by attorneys (which appear prominently in his notes at several junctures). As Braudel warns, "Money was indeed a miraculous agent of exchange, but it was also a confidence trick serving the privileged." 15 If great advantage lay in paper money and credit, so did great treachery and betrayal of public trust.

Like words that connote values such as goodness or honesty, money-especially paper money-merely signifies. As a medium it is so transparent or invisible it can be "Pregnant with thousands" but still "flits ... unseen" (echoing the earlier line: "Oh! that such bulky Bribes as all might see"). The powerful paper scraps should not be strictly identified nor equated with wealth or capital. But a society can easily develop a monetary economy based on paper rather than on actual wealth. For example, it has been estimated that the amount of metal on deposit at the Bank of England by the end of the seventeenth century was a mere 7 percent of the outstanding value of paper notes - not 50 percent, as some contemporaries assumed. ${ }^{16}$ In a manner similar to accepting the face value of paper money or bonds as representing the true worth of society's production of goods, social usage easily lets words and rumor, not deeds, pass for its members' virtue and reputations. Easy virtue, easy money, easy words: all with more in common than their modifier.

As we have seen, the connection between writing and money had for several centuries been deeply embedded in European financial practices, not through government issue, but in the form of bills, shares, and private banking notes. Pope regards Sir John Blunt as the "great Scriv'ner!"-here literally a money writer. Blunt was a key director for the South Sea Company, which tried to buy the national debt, the difference between the Bank of England's reserves in metal and its outstanding paper notes. The debt had in effect been created by writing, and it was now to be resolved by scriveners and paper credit. "The scrivener," Peter Dixon remarks, "combined the functions of estate-agent, broker, money-lender,

14/Perhaps following Courthope, Paul J. Alpers, "Pope's To Bathurst and the Mandevillian State," in Essential Articles for the Study of Alexander Pope, ed. Maynard Mack, rev. and enlarged (Hamden, Conn., 1968), pp. 493-94, suggests Pope opposed paper currency. Wasserman (pp. 33-34) corrects Courthope's opinions: "Pope obviously does not regard currency 'solely as an instrument of corruption." There was precedent, however, for widespread use of paper currency to lapse. Parts of China enjoyed paper money from the ninth through fourteenth centuries, but it passed out of circulation. Silver bullion replaced it until paper was reintroduced in the 1880s. See John K. Fairbank, Edwin O. Reischauer, Albert M. Craig, A History of East Asian Civilization, 2 vols. (Boston, 1960-65), 1:219, 279, 303; 2:97-98.

15/Fernand Braudel, The Wheels of Commerce, trans. Siân Reynolds (New York, 1982; Paris, 1979), p. 426.

16/See Wasserman (p. 25n.), who derives the 50 percent figure from A Discourse of Trade, Coyn, and Paper Credit (1697) by Henry Pollexfen. 
and solicitor, and operated with a freedom unknown to his modern counterparts." 17 The wonder of the public debt was that it was not long term but perpetual, yet any holder could gain personal liquidity by selling shares to someone willing to assume the role of creditor.

When writing becomes money, deeper possibilities of subterfuge include fraud, forgery, and counterfeiting - all similar crimes of false writing and signature. John Ward was guilty of forgery, and perhaps Blunt falsely conveyed, to Ward, part of his estate (Pope later dropped mention of this charge). Peter Waters - or Waltertoo, is a money scrivener or writer who loans out at interest. The power of such scriveners was, as Braudel observes with anecdotal evidence, "a constant source of amazement. The Italian merchant who settled in Lyons in about 1555 with a table and an inkstand and made a fortune represented an absolute scandal, even in the eyes of people who understood the handling of money and the process of exchange fairly well." ${ }^{18}$ Moreover, as Pope reports, Blunt grew "eloquent" and "declaimed against the corruption and luxury of the age" in prophetic style. His money writing was false or inflated, and his junk bonds became heavily discounted. The same happened with his florid rhetoric, often phrased as national prophecy. And how was it that Blunt came to make such promises and predictions, resulting in his paper scheme? "A wizard told him in these words our fate." The sense of false prophecy again is emphasized, here with a hint of Walpole as Lord Treasurer. ${ }^{19} \mathrm{We}$ can think too of the pledge, again a verbal or written act, that the Charitable Corporation, along with one of its chief directors Denis Bond, made in order to help the deserving poor. Bond ends by damning them "and hates them from his heart." The easy, always available deception of writing and speaking now entails direct deception in the use of riches, the two systems having become virtually equated in their abuse.

\section{III}

Looking over Pope's notes, we see worth constantly punctuating them. He indicates the wealth of individuals by saying how much they are "worth" in terms of pounds, often italicizing worth in bitter, mocking emphasis. One obvious play on worth comes in the note to Waters: "But this gentleman's history must be deferred till his death, when his worth may be known more certainly." ${ }^{20}$ Here Pope uses "worth" in its obverse and reverse senses. He seems to be waiting for Waters's funeral (as he had waited successfully for John Hopkins's in 1732) to add "-lessness." But Walter would not die until 1746. The desired transvaluation Pope achieves instead by describing Hopkins, barely cold, as one who "lived worthless, but died worth three hundred thousand pounds."

The final tale of Balaam also links material well-being and virtue, assigning worth in both those senses through the intervention of death, which settles all accounts. Immediately preceding the tale we hear

17/Dixon (n. 1 above), p. 139.

$18 / C M L$, p. 358 .

19/The lines recall Rape 5.139-40, referring to Partridge the astrologer: "And hence th'Egregious Wizard shall foredoom / The Fate of Louis, and the Fall of Rome."

$20 /$ Wasserman (p. 29) cites worth and other puns on lend and affords, where money language and moral language criss-cross. 
Cutler and Brutus, dying both exclaim,

"Virtue! and Wealth! what are ye but a name!"

[Lines 333-34]

Each a mere word? Is there some higher system of value that will save or damn the soul that exercises or abuses its virtue and wealth? Pope's final examination of word, wealth, and worth - of language, money, and virtue (or lack of it) - comes in Balaam's portrait. The stage is set by the next lines, with the key phrase "such worth" referring back to wealth and virtue both:

Say, for such worth are other worlds prepar'd?

Or are they both, in this their own reward?

A knotty point! to which we now proceed.

But you are tir'd - I'll tell a tale. "Agreed."

When Balaam is introduced, "His word would pass for more than he was worth" (line 344). Before his downfall, or perhaps we should say before his meteoric rise, his word was better than his written bond, his language to be trusted to the utmost degree if one were dealing financially. But if worth is the name for virtue, the line inverts its meaning and Balaam becomes a hypocrite or, as in earlier interpretations of him, a false prophet. What happens to Balaam's word is curious. As his money grows, his word declines until it descends, like Bond damning the poor, into a curse. ${ }^{21}$ The whole play on worth and words emerges, moreover, as a possible aural pun. Elizabethan pronunciation makes a final $t h$ into $t$-as in Shakespeare's quibble on death and debt between Falstaff and the Lord Chief Justice. So worth becomes wort, close to word, and identical to the German word. This perhaps seems far-fetched, but we might recall the lineage of the House of Hanover. Any $t h$, at least in the mouth of George I, would have been $t$, his wort, another name for word. This verbal pairing is evoked again by Johnson in his imitation of Juvenal's third satire, London, where Thales decries the fact that worth is not even praised in worthless words:

Since Worth, he cries, in these degen'rate Days Wants ev'n the cheap Reward of empty Praise.

[Lines 35-36]

But to return to Balaam, his exemplum contains a further, related connection between the use of riches and the use of language. Indeed, throughout the poem wealth or worth is bound up, as in Cutler's and Brutus's exclamation, with names and naming - with what others call us and what we call them-and (not always the same) with what things, and even human beings, actually are. Names seem to change with the person's worth or supposed value. The Man of Ross helps to build a church and raise its steeple. But in the church he "Will never mark the marble with his Name." 22 In fact, as Pope explains, his "true name was almost lost," and Pope had to write Jacob Tonson to ascertain "his Xtian and surname." ${ }^{23}$ By his

21/See Wasserman (n. 2 above), pp. 29, 46, 48. An attempt to link worth and word etymologically refers to Indo-European forms of wer. But "worth," like OE weard, derives from a base meaning "bound up in or involved," while "word" developed from a suffixed form of wer akin to Greek rhetor.

22 /Wasserman (p. 44) suggests this reflects the "scribbling on the walls of London Houses," a form of graffiti.

23/Bateson (n. 5 above), p. 110n. 
virtuous works, and by the simple lines in the Parish Register, the Man of Ross is instead "Prov'd, by the ends of being, to have been." (Similarly, in Eliot's Silas Marner, one character argues that marriage really occurs not with the couple's love or vows, nor with what the minister pronounces, but only with the signing of the Register.)

Balaam, too, ironically begins "A plain good man"- a title sounding quite like the Man of Ross - "and Balaam was his name." But then, poking fun at Puritan hagiography, Pope reports "the Dev'l was piqu'd such saintship to behold." With newfound riches, clearly of the written kind, the plain Citizen not only becomes someone different-and frighteningly more like everyone else already is ("Sir Balaam now, he lives like other folks")- he names everything else in different fashion as well:

Behold Sir Balaam, now a man of spirit, Ascribes his gettings to his parts and merit, What late he call'd a Blessing, now was Wit, And God's good Providence, a lucky Hit. Things change their titles, as our manners turn,

[Lines 375-79]

Or, we might conclude, as Balaam's own title turns.

This change in judgment - and the alteration of the names we use for things as a result of financial success - runs a course close to that in the Essay on Criticism, where judgment of an author's language is determined by rank or "Quality" and its associated wealth.

Some judge of Authors' Names, not Works, and then

Nor praise nor blame the Writings, but the Men.

Of all this Servile Herd the worst is He

That in proud Dulness joins with Quality,

A constant Critick at the Great-man's Board,

To fetch and carry Nonsense for my Lord.

What woful stuff this Madrigal wou'd be,

In some starv'd Hackny Sonneteer, or me?

[Lines 412-19]

The "fetch and carry" of the false critic plying his Lord with written trash reappears in Bathurst to characterize the devious servant of paper wealth, who turns out to be the real master able to "fetch or carry Kings." (In the Epistle to Dr. Arbuthnot, line 226, "To fetch and carry sing-song up and down," voices Pope's scorn for the "race that write." The passage contains an ironic slight of George II as well.)

Finally the Devil, always a fine (though false) rhetorician on the evidence of both Miltonic epics, whispers, tempts, and persuades Sir Balaam completely. Language as well as wealth is the diabolical medium, and the Devil masters both by making them one. What captures Sir Balaam's soul is his attainment of the ironic title "Director." And the Devil "dubs" him this, the verb reinforcing an irony that equates the royal act of bestowing knighthood with dubious gain in Exchange Alley.

But how does the Devil actually secure the soul of Balaam? The traditional form of such an arrangement is an instrument of conveyance or actual security itself-something signed-a pact with the Devil where the contract is attested to by 
actual signature. The classic example is Faust's pact witnessed by the Devil's agent or risk arbitrageur Mephistopheles. In Marlowe's Doctor Faustus, the learned man writes such a "bill" in his own blood:

What might the staying of my blood portend?

Is it unwilling I should write this bill?

After writing Faustus says, "this bill is ended" (1.5). It is also called a "scroll" or "deed." Though Pope does not explicitly mention that directors sign stock and notes, everyone knew the practice well. We can extrapolate a little to see how Balaam's situation entails a compact with the devil, which is represented as the writing of such a bill. As Director, Sir Balaam becomes obliged to sign the securities of the Corporation or Bank. ${ }^{24}$ In a sense, signing is his most important act, just as the chief financial officer of a government must sign printed currency to make it good. Balaam's pact with the Devil is thus completed and reinforced each time he writes his name on a note or bond showering "Cent. per Cent." The Devil's contract is each signed security, and he can afford to keep plenty of spare copies on hand.

\section{IV}

On the more optimistic side of the relation between wealth and words in the poem, we discover that for Pope the best use of riches and the best use of words are both directed by the same quality of intellect and personal character. What guides the finest exercise of wealth is "Sense,"

\footnotetext{
The Sense to value Riches, with the Art T'enjoy them, and the Virtue to impart, Not meanly, nor ambitiously pursu'd, Not sunk by sloth, nor rais'd by servitude.
}

[Lines 219-22]

This formulation resonates with the same "good Sense" that should govern writing and criticism. Excess in verbal style Pope compares to gold and jewels that ostentatiously "cover ev'ry Part" in a mass (Essay, lines 295-96); so in Bathurst wealth "In heaps, like Ambergrise, a stink it lies." In moral economy, too, as Clarissa reminds Belinda in The Rape of the Lock, "good Sense" is a guiding light of conduct. It, and not the outward sign of a pretty face, maintains virtue in the theater's front box. In Bathurst the gambling and corruption caused by paper money make peeress and butler each lose their sense and share the same-dice, theater, sexual-box. (The loose mores in Balaam's tale have their analogy in contemporary references to paper credit as promiscuous copulation. Fitting in with this fornication, the shower of "Cent. per Cent."-as Maynard Mack and others observe - alludes to Jove descending on Danaë as a shower of gold.)

Finally, in the connection between criticism and spending, the Essay on Criticism (lines 578-79) metaphorically fuses the Sense of language with the cent.'s of wealth: 
Pope applies the idea of a golden mean with equal appropriateness to the use of riches and the use of language. Bathurst exemplifies it, or at least Pope asks him to do so (lines 219-28). And Pope's address to him is cut from the same cloth as the description in the Essay on Criticism (lines 631-42) that calls for critics to practice a golden mean in literature. In Bathurst there is even a hint that if the Man of Ross were a poet, his works would be "clear and artless" as the river he bade flow.

Who hung with woods yon mountain's sultry brow?

From the dry rock who bade the waters flow?

The Man of Ross exercises true wit in the use of riches, for what he does is precisely to produce "Nature to Advantage drest." In clear and artless style he gives us the "true expression" of riches and "without method" shows us their sense. ${ }^{25}$

The Epistle to Bathurst intermingles two of the most important and pervasive semiotic systems of society, words and wealth, writing and money, at a time whenduring Pope's own life - they were becoming closely, at times indistinguishably, conjoined. "For money is a language (we too must be forgiven for using a metaphor)," says Braudel; "it calls for and makes possible dialogues and conversations; it exists as a function of these conversations." ${ }^{26}$ Each system, money and language, is a powerful signifier of value. But behind them both stands the larger quality of Sense, of virtue as human action, the benefit or damage caused by motives directing the use of words and wealth.

Virtue is thus far more than the mere signifiers of its worth, whether words or paper notes, a syllable or a leaf: virtue becomes what we do with-and, also, inescapably within - the semiotic systems at hand, how we bestow value through motive and acts. This all stands behind what Howard Weinbrot sees as the guiding principle of the poem, how "virtue is not just a word but a concept of active benevolence that has its pattern in heaven and heavenly workings." 27

\section{$\underline{\mathrm{V}}$}

We can return once more to Sir Balaam, having left him a knight and Director signing endless contracts with the Prince of Air, into whose arms the paper notes and government currency fly, swirling like so many misdirected Sibylline leaves. The modest means belonging to the Man of Ross he distributed in kind to the poor, or employed to raise public works, or to build an aspiring steeple for a church without his name. His works eliminated written money, making scriveners and "vile Attornies" into "an useless race." Sir Balaam, on the other hand, resorts to small coins to do his good works and salve his conscience: "I'll now give six-pence where I gave a groat." Written money was too dear for such charity: having started paper notes with the smallest sum at $£ 20$, the Bank for a time issued $£ 5$ notes but finally settled on $£ 10$ as the lowest denomination. But the Charitable Corporation, in fact, specified forwarding only "small sums" to the industrious poor. At that level coins

25/See Essay on Criticism, lines 315-17, 653-54. Many critics note the similarity of the golden mean in Bathurst with passages in other poems of the "Opus Magnum" 1729-44, e.g., An Essay on Man, 4.15594, 357-60,

26/CML (n. 4 above), p. 328.

27/Weinbrot (n. 2 above), p. 179; see also p. 315: "In the Horatian epistle to Bathurst, Pope made clear that Virtue was not an empty word." Weinbrot compares this with virtue becoming an "empty boast" in One Thousand Seven Hundred and Thirty Eight. 
had to be employed; paper money was out of the question. So Bond and a majority of the Directors of that Corporation decided to take their considerable assets and invest them in the City: "Damn the Poor," said Bond, "let us go into the City, where we may get [paper] Money." ${ }^{28}$ As a similar Director, Balaam's own fortune comes from paper's "Cent. per Cent.," where the use of riches is mad self-propagation.

In Pope there is almost always another nuance. He caps Balaam's rise to M.P. in this manner:

And St. Stephen's gains one Pensioner more.

The connection with the Commons and Walpole is evident. ${ }^{29}$ Sir Balaam has become an inside trader, a team player in a situation where government economic policy is a form of state religion. His pension is of course a bribe, and we can recall Johnson's definition equating the two, or his lines from London echoing Juvenal's image: "Here let those reign, whom Pensions can incite / To vote a Patriot black, a Courtier white." (Pope said he would be glad to take credit for the anonymous London, and many first gave it to him.)

The House of Commons continued to meet in St. Stephen's for a century after Bathurst was published. St. Stephen's, however, was originally a Catholic chapel, built by the Edwards to emulate or surpass Sainte Chapelle in Paris. Only after the Reformation did it assume a Parliamentary character. Sir Christopher Wren put it into a plain style (much like Balaam's original self) about 1707. In contrast, the Man of Ross helped to build a "heav'n-directed" steeple and refused to desecrate it with his name. (Wasserman, pp. 64-65, draws attention to Pope's manuscript alteration of "Town" to "Church," and in later versions stressing even more the presence of the church, first without a stone to mark Kyrle's grave [pp. 92-93], and then "witht any Stone or Inscription" [pp. 122-23].) But "Vulture Hopkins" commissions (so Pope mistakenly thought) a vile statue of himself to bear up God's altar. To cap these contrasts, Balaam is first seen under London's pagan-like column, not "heav'n-directed" but simply "pointing at the skies," its false inscription imputing the Great Fire to Papists and its shaft overlooking Exchange Alley where the paper schemes were hatched. ${ }^{30}$ Next Balaam receives a bribe from what was once a consecrated Catholic chapel, its original identity now defaced, its new brand of morning worshiper pouring in the door. St. Stephen's becomes the Sibyl's cave, her leaves its paper bribes, and its wizard prophet, its satanic anti-Christ, Walpole. To bring this theme of inscribed (or erased) places of worship up to date: the column's inscription was erased in 1831, fire burned St. Stephen's in 1834, and Twickenham is at present a convent school.

But then to this line about St. Stephen's (394), home of the new written word, Pope appends in 1735 a cryptic note: “- -atque unum civem donare Sibyllae. Juv[enal]." ${ }^{31}$ This quotes part of the third line of Juvenal's third satire. Wasserman

28/Bateson, p. 96n.

29/See Wasserman, p. 54.

30/For details, see Vincent Carretta, "Pope's Epistle to Bathurst and the South Sea Bubble," Journal of English and Germanic Philology 77 (1978): 229. Carretta provides a strong argument for the poem's immediate political aims connected with the still fresh South Sea scandal and Bathurst's role in the Opposition.

31/ Elwin and Courthope (n. 13 above), 3:158. 
interprets Pope's citation, “Just as Sir Balaam has made his progress from the City to St. James and thence to St. Stephen's Chapel in Westminster, where Walpole performs his mysteries, so Juvenal's friend, Umbritius, is escaping Rome to live in Cumae, where the Sibyl has her shrine and prophesies men's futures. . . but the irony, of course, lies in the fact that whereas Umbritius was escaping to the simple, agrarian culture of Cumae, Sir Balaam has fled from sordid London to the very source of its corruption." ${ }^{32}$

Wasserman's reading is certainly à propos. But an additional level of allusion may be at work, especially in view of the strong references earlier in the poem to the Sibyl and her association with paper money, credit, and bribes. Pope perhaps knew that it was in the reign of Caesar Augustus that the Sibylline Books were established in a new locale. At that time they were transferred to the temple of Apollo Palatine, not at all in the country but near the imperial residence. Their transfer to that marble temple, built in 28 B.C., one year after Octavian became Augustus, meant he could hold special worship in the presence of those leaves. By his brief note, Pope not only associates the tone of his poem with Juvenal's satire; he appears also to implicate Augustus, for Augustus himself, who customarily worshiped Apollo in the Palatine temple, oversaw the transfer of the Sibylline Books there. The Roman echoes are strengthened by Pope's mention, in the previous line, of "Britain's Senate," which, like Rome's, has been bought out by the Emperor and his ministers. Moreover, Pope's poem was first published just one day before the king opened Parliament in 1732/3.

The terse Juvenalian reference opens multiple perspectives. St. Stephen's, once a prized chapel of Catholic royalty, becomes Apollo's temple on the Palatine, the ruling Party's new church and place of false prophecy. To it are transferred the latter-day Sibylline Books, and with them-or as wizard Walpole's leaves out of them - the government bribes doled out to "pensioners" in paper notes, shares, and false conveyance of estates. And as those books played a vital role in Roman religion, Pope casts paper money (and especially the paper instruments on which Balaam and the government gamble their fortunes, and the country's) as essential to Britain's new religion, its ministers, and its Augustus-all of whom are not so obliquely identified as business associates with the Devil, King of Whirlwinds. If we take Pope's note to Juvenal as primarily a reference to Cumae, we might ask why he quotes only the third line but not the second, which names Cumae explicitly. Even stressing the parallel with Cumae rather than with the Sibylline Books, we might pause to reflect on what Gibbon intimates in the Decline and Fall, that during his lifetime Augustus received worship as a god in several temples dedicated to him. One was at Cumae. ${ }^{33}$

The gold from God, or the paper shower from Jove, funnels through Balaam back to Augustus. Devil and King go snacks: the souls go to Satan, the paper money, stocks, and so forth, to the Crown. In one manuscript version of the line, "The Devil and divide the prize," Pope had written, then erased, "the King." ${ }^{34}$ Indeed, in manuscript versions this line does not always appear, and it is

32/Pp. 54-55, where Wasserman also calls attention to the irony of St. Stephen's name, since the saint was the most important of deacons in charge of distributing alms to the church's needy "pensioners."

33/Edward Gibbon, The History of the Decline and Fall of the Roman Empire, ed. J. B. Bury, 7 vols. (London, 1909), 1:76 and $\mathrm{n}$.

34/ Wasserman, pp. 102-3. 
lacking in the first edition of 1732. But Pope finally added or included it, with the erased words printed out. ${ }^{35}$ George II, Augustus, collects his due, and unto Caesar is rendered what is his.

When paper credit was introduced to France by the Scottish economist John Law (whose scheme Blunt professed to emulate), the Princess Palatine-her title here a pure coincidence-exclaimed: "I have often wished that hell-fire would burn all these notes,' and swore that she understood nothing of the detestable system." In the case of Pope's Balaam, depicted with such representative and compressed brilliance, the Princess is far from getting her wish. Instead, it is the souls that burn. The notes are forfeit-that is, they revert-to Augustus. Presumably they are blown into his Sibyl's hands again. At any rate, "this uneasiness," exhibited so forcefully by the Princess and so many others, says Braudel, "was the beginning of the awareness of a new language." "36 Pope, master of Locke's "usual" semiotic system of words, understands with the same acuity the implications and machinations of the unusual new system of money writing, particularly as an instrument of social behavior and national policy. At bottom, at least for Pope, their common rate of exchange is moral sense, or its corruption.

Receipt of a bribe from France disclosed - bereft of family, place, and meansimpeached in the House of Lords and now about to hang-poor Balaam at last curses and thus employs the old language in its linguistically sinful sense. ${ }^{37}$ The corrupt systems of words and wealth, unscrupulously fused as one, have corrupted him. Here there is no room for casuistry or polite debate, no Buchgeld. The account must be paid in the soul's currency. His very wind cut off by the rope, Balaam's last word is nevertheless the most impious of performative speech acts. He damns God. And in doing so, he can also be heard cursing what was God and was with God in the beginning - before paper money, even before gold - the Word.

Harvard University

35/Compare, for instance, Wasserman, pp. 102-3, 130-31.

36/CML, p. 328.

37/See Job 2:9; Balaam echoes Bond, who in line 102 damns the poor. 